\title{
Mobile Maintenance Workspaces: Solving Unforeseen Events on Construction Sites More Efficiently
}

\author{
Elke Hinrichs \\ Fraunhofer FIT, Sankt Augustin, Germany \\ May Bassanino, Colin Piddington, Gilles Gautier, Farzad Khosrowshahi, Terrence Fernando \\ University of Salford, Salford, UK
}

Jens Ove Skjærbæk

COWI, Aalborg, Denmark

\begin{abstract}
This paper presents the process of solving unforeseen events on construction sites - a frequent phenomenon throughout the industry. The current process of handling an unforeseen problem is described and contrasted with a future scenario in which I\&C technologies are applied to solve unforeseen problems on large construction sites more efficiently: augmented reality, positioning technology, knowledge support and involvement of remote experts. The Mobile Maintenance Workspace, a range of applications to support mobile workers in their maintenance work, and its underlying software framework is outlined. The work presented here is currently being carried out in the European Integrated Project CoSpaces.
\end{abstract}

\section{MOTIVATION}

The construction industry is faced with a dilemma that until, and even while, building is in progress some problems are not foreseen and this has impact on the handover time to the customer. This invariably implies default and penalty clauses that affect the profitability and the ROI (return of investment) for the builder. As building realization necessarily uses local labour, plans and construction information are not always interpreted correctly in line with the design intent and the architect's vision.

These frequent unforeseen situations require a decision or action urgently. Such decisions often require a chain of authorization involving a diversity of actors. These situations may fall outside the responsibility of the operative on site, though he/she might, nonetheless, initiate a decision or knowledge acquisition process that is likely to engage these actors and other experts. All these events could be categorised under the umbrella of 'unforeseen events' on site, which could take various forms such as health \& safety concerns and constructability difficulties. In such situations, there is a need for extensive collaboration between various actors as well as the need for external expertise which could take the form of human expertise or be present in the form of information or knowledge by accessing the relevant sources. However, the fragmented nature of construction projects inhibits orchestrated and fast decision making. Furthermore, the site-based constraints do not allow seamless access nor access across organizational boundaries to the knowledge that is required to support the collaboration and decision making processes. Given the fragmentation, the number of actors and the nature of their business, it is difficult but imperative that problems are addressed and resolved as early as possible. The adverse effect of disruptions is likely to escalate the problem by disrupting the flow of progress with a potential domino effect on the remaining construction activities. This is likely to extend the duration of the construction project and the rescheduling of the programme may result in one or more contributors not being available thus creating further disorder. When considered in conjunction with the potential legal implications of these interruptions the adverse impact could be detrimental to the overall success of the construction project.

In view of the above, it is envisaged that an improvement in the communication and collaboration processes is likely to have considerable impact on the success of the construction project which is measured in terms of project total cost, duration and quality. The introduction of collaboration technology may result in the reengineering of the problem solving process, this then leading to a further increase in productivity.

\section{UNFORESEEN EVENTS AT CONSTRUCTIONS SITES}

This mobile scenario considers the situation facing a small or medium enterprise (SME) who is attempting to install piping services to a previously installed HVAC (heating and ventilation air conditioning) system by another SME. The problem created is that 
there is insufficient space and access to install the supply pipe as the prescribed space in the working order is already taken by apparently wrongly placed installations.

Both SMEs are working for a main contractor, who is carrying the overall responsibility for site operations. The stakeholders for this class of general scenario (unforeseen problems) are presented in Figure 1.

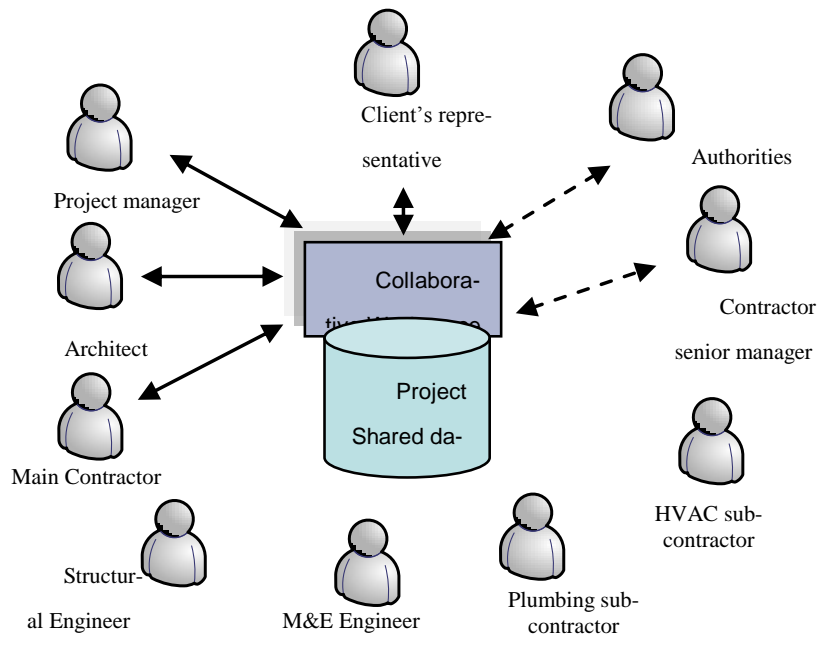

Figure 1: Stakeholders of the unforeseen problem scenario

The scenario is a derivative of a more generic case associated with the occurrence of 'Unforeseen Events', where there is a need for information and decision-making from a variety of stakeholders to resolve the problem as early and efficiently as possible. An unforeseen event could relate to risk matters, hazard and emergency issues. It could take various forms and shapes, such as unforeseen design faults, or issues pertaining to buildability (or constructability), site logistics, health \& safety, hazard spotting. Several objectives could be speculated as being associated with this scenario. These could vary from legal to promotional and professional imperatives. A range of generic objectives include: cost minimization/profit maximization, following rules, aiming to attain glory, quality assurance and rules and regulation compliance, risk evasion/management, problem ownership, impact assessment and performance competency measures (e.g., key performance indicators).

In all situations the main objective is to reach a resolution in the most efficient way and in the minimum of time, without excessive cost implications. This is to be achieved through better means of communication in an efficient collaborative setting. This includes better and faster communication of information and decisions.

\subsection{The scenario: an unforeseen problem at a construction site}

After the installation of the plumbing and ventilation system in a basement, the SME1 operator arrives on site to install a pipe but realizes there is a pipe collision problem (Figure 2). There is not enough space left by the existing pipe installations and he can not install the pipe as the wrongly accepted ventilation shaft has been mounted before. The shaft is $5 \mathrm{~cm}$ wider than described in the project and in the specification to the supplier. The existing pipe installations supply $\mathrm{H} / \mathrm{C}$ water and steam. Under the pipe installation the electricians have already mounted the cable trays for cables and their work is halfway to completion.

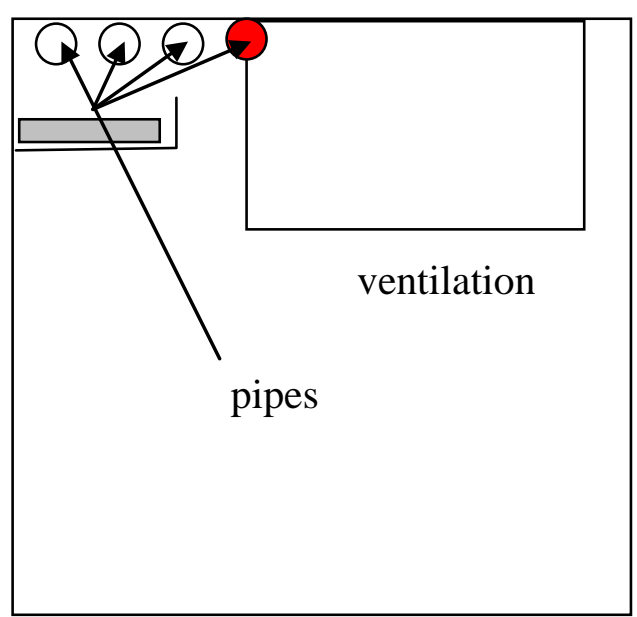

Figure 2: Clash between the pipe and the ventilation system

The stakeholders involved in the scenario are represented in the following table:

Table 1: Stakeholders in the construction scenario

\begin{tabular}{|c|c|}
\hline Stakeholder & Role \\
\hline $\begin{array}{l}\text { Project Manager } \\
(\mathrm{PM})\end{array}$ & $\begin{array}{l}\text { represents the Main Contractor - based } \\
\text { on site }\end{array}$ \\
\hline $\begin{array}{l}\text { Client's Representa- } \\
\text { tive }\end{array}$ & $\begin{array}{l}\text { represents the client, controls quality, } \\
\text { cost and time on site }\end{array}$ \\
\hline Architect & $\begin{array}{l}\text { produces the architectural design and } \\
\text { drawings }\end{array}$ \\
\hline $\begin{array}{l}\text { Structural Engineer } \\
\text { (SE) }\end{array}$ & $\begin{array}{l}\text { produces the structural design and } \\
\text { drawings }\end{array}$ \\
\hline M\&E Engineer & $\begin{array}{l}\text { produces the Mechanical Engineering } \\
\text { design and drawings }\end{array}$ \\
\hline $\begin{array}{l}\text { Plumbing Sub- } \\
\text { Contractor (SME1 } \\
\text { foreman) }\end{array}$ & plumbing work - based in the office \\
\hline SME1 operator & $\begin{array}{l}\text { in charge of installing plumbing work } \\
\text { on site }\end{array}$ \\
\hline $\begin{array}{l}\text { HVAC sub-contractor } \\
\text { (SME2 foreman) }\end{array}$ & $\begin{array}{l}\text { heating, ventilation and air condition- } \\
\text { ing work - based in the office }\end{array}$ \\
\hline SME2 operator & $\begin{array}{l}\text { in charge of installing HVAC work on } \\
\text { site }\end{array}$ \\
\hline Quantity Surveyor & responsible for estimates \\
\hline Contractor Senior & being reported to by $\mathrm{PM} \mathrm{-} \mathrm{based} \mathrm{in} \mathrm{the}$ \\
\hline Manager (CSM) & company \\
\hline Commercial Director & evaluates cost implications \\
\hline Authorities & $\begin{array}{l}\text { e.g.: fire, environment, police, plan- } \\
\text { ning, etc. }\end{array}$ \\
\hline
\end{tabular}


The SME1 operator communicates with his/her SME1 foreman to report the problem. The SME1 foreman tries to get in touch with the site project manager. If he/she is on site, he will investigate the problem, if not, the SME1 foreman has to wait, which might take up to half a day. When the SME1 operator finds the project manager, they try to see if the pipe can be placed in another position. After checking the drawings, however, the project manager and SME1 find that this is not possible and that the ventilation shaft takes up too much space in contradiction to the design. At this stage, the job is falling behind as a change has happened and so there is a need to raise a request for a design change.

The project manager now communicates with the SME2 foreman to brief him about the problem. One of the problems identified here in the construction industry is that the Main Contractor (or the project manager) talks one language, and the SMEs (subcontractors) each talk different languages due to domain terminology. This sometimes results in confusion, hence cost increases and time delays that might partially be solved by sharing more visual than textual information.

The project manager, the SME1 foreman and SME2 foreman will try to speculate on the source of the problem. After further checking, the problem seems to be design related. So far no solution has been determined.

The project manager at this point consults his design team to identify whose fault it is. The M\&E engineer who did the specifications will try to find someone to pass the blame on to (blame culture). If it is an error in design, he will try to correct it and give solution to the project manager. If it is not a design problem, then he will try to see if it is an implementation or control problem. The project manager liaises with the appropriate consultant(s) from the design team to get clarification of the problem and come up with a solution. A site meeting then needs to be organized. So the project management decides to have a face to face meeting on site with the design team to review and discuss the problem and to look at the various solutions in cooperation with the SME1, SME2, and the design team.

The project manager, the two SME foremen and the design team all have a meeting on site. After studying the drawings, they agree it is a supply fault of the supplier and partly of the SME2, as they did not report that the shaft was in a size other than prescribed. There is now a delay of several weeks on site, while the project manager communicates with the contractor senior manager and reports to him to get authority to suggest alternative solutions, as well as confirmation that he is heading in the right direction. He is also communicating with his commercial director for any cost implication or contractual issues.
Next, the client representative organizes a meeting between the M\&E engineer and the structural engineer to accommodate the extra pipe and also to decide the change specification. The project manager asks his quantity surveyor for a cost estimate for the work.

Then the client representative communicates with all the relevant consultants from the design team such as the engineers, the SME1 foreman and the SME2 foreman as well as all the regulatory authorities (such as fire, building control, environment, police and planning) to provide an approved solution taking practicalities into account.

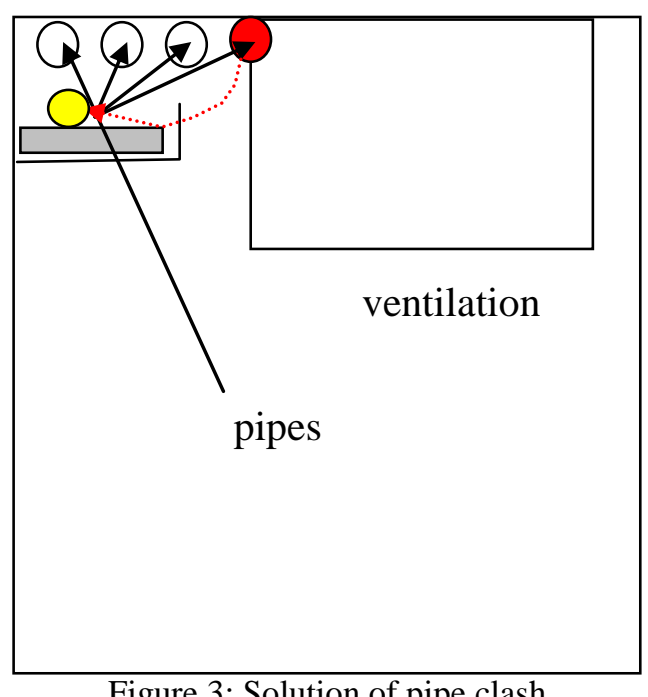

To replace the ventilation shaft with a new one matching the prescribed size would be far too expensive. The electrical installation cannot be moved and the only solution is to mount the natural gas under the cold water pipe using a special suspension that needs approval from the authorities before final acceptance of the solution.

The newly approved variation specification that was done by the engineers will now be sent to the SMEs for costing variation. The project manager then contacts the contractor senior manager to get a final authorization to go ahead with the work and install the pipe. By order from the client's representative, the project manager communicates with the SME1 foreman and provides him with new specification and signs the variation document.

\subsection{Process}

The process as describe above can be summarized as follows:

Table 2: The process of solving unforeseen problems - current practices

\begin{tabular}{llll}
\hline & Actor & Action(s) & Result(s) \\
\hline 1 & SME1 opera- & identifies problem & $\begin{array}{l}\text { problem: pipe col- } \\
\text { lision }\end{array}$ \\
& tor & & report (oral) \\
& $\begin{array}{l}\text { SME1 opera- } \\
\text { tor } \rightarrow \text { SME1 } \\
\text { foreman }\end{array}$ & reports problem & \\
& & &
\end{tabular}




\begin{tabular}{|c|c|c|c|}
\hline & Actor & Action(s) & Result(s) \\
\hline 3 & $\begin{array}{l}\text { SME1 foreman } \\
\rightarrow \text { PM }\end{array}$ & $\begin{array}{l}\text { reports problem; } \\
\text { consults drawing, } \\
\text { tries to find quick } \\
\text { solution }\end{array}$ & no success \\
\hline 4 & $\begin{array}{l}\mathrm{PM} \rightarrow \mathrm{SME} 2 \\
\text { foreman }\end{array}$ & briefs & \\
\hline 5 & $\begin{array}{l}\text { PM + SME1 } \\
\text { foreman }+ \\
\text { SME2 foreman }\end{array}$ & $\begin{array}{l}\text { speculates on } \\
\text { source of problem }\end{array}$ & $\begin{array}{l}\text { seems to be } \\
\text { supply related } \\
\text { problem }\end{array}$ \\
\hline 6 & $\begin{array}{l}\mathrm{PM} \rightarrow \\
\text { SME1/SME2 } \\
\text { foremen+engin } \\
\text { eers }\end{array}$ & $\begin{array}{l}\text { site meeting: con- } \\
\text { firms source of } \\
\text { problem }\end{array}$ & $\begin{array}{l}\text { confirms supply } \\
\text { related problem } \\
\text { by deliverance of } \\
\text { wrong ventilation } \\
\text { system: lack of } \\
\text { space, various } \\
\text { proposals for so- } \\
\text { lution }\end{array}$ \\
\hline 7 & $\begin{array}{l}\mathrm{PM} \rightarrow \text { Con- } \\
\text { tractor Senior } \\
\text { Manager }+ \\
\text { Commercial } \\
\text { Director }\end{array}$ & $\begin{array}{l}\text { informs for autho- } \\
\text { rization to initiate } \\
\text { solution process; } \\
\text { consider costs, le- } \\
\text { gal, procedural } \\
\text { implications }\end{array}$ & $\begin{array}{l}\text { authorization \& } \\
\text { confirmation of } \\
\text { course of action }\end{array}$ \\
\hline 8 & $\begin{array}{l}\text { M\&E Engineer } \\
\rightarrow \text { architect }\end{array}$ & $\begin{array}{l}\text { instruction to ac- } \\
\text { commodate pipe }\end{array}$ & revised design \\
\hline 9 & $\begin{array}{l}\text { PM } \rightarrow \text { Quanti- } \\
\text { ty Surveyor }\end{array}$ & $\begin{array}{l}\text { asks for cost esti- } \\
\text { mates }\end{array}$ & cost estimates \\
\hline 10 & $\begin{array}{l}\text { PM } \rightarrow \text { M\&E } \\
\text { engineer + } \\
\text { architect: site } \\
\text { meeting (con- } \\
\text { sultants: struc- } \\
\text { tural, electric- } \\
\text { al) + SME1 } \\
\text { foreman + } \\
\text { SME2 foreman } \\
\text { + regulatory } \\
\text { authorities } \\
\text { (fire, building } \\
\text { control, envi- } \\
\text { ronment, po- } \\
\text { lice, planning) }\end{array}$ & $\begin{array}{l}\text { site meeting with } \\
\text { consultants (struc- } \\
\text { tural, electrical): } \\
\text { discuss solution } \\
\text { and consider prac- } \\
\text { ticability issues }\end{array}$ & $\begin{array}{l}\text { agreement on so- } \\
\text { lution }\end{array}$ \\
\hline 11 & SMEs & $\begin{array}{l}\text { verify cost impli- } \\
\text { cations }\end{array}$ & $\begin{array}{l}\text { cost estimates, re- } \\
\text { vised }\end{array}$ \\
\hline 12 & $\begin{array}{l}\mathrm{PM} \rightarrow \text { Con- } \\
\text { tractor Senior } \\
\text { Manager }\end{array}$ & $\begin{array}{l}\text { asks for final au- } \\
\text { thorization }\end{array}$ & final authorization \\
\hline 13 & $\begin{array}{l}\mathrm{PM} \rightarrow \mathrm{SME} 1 \\
\text { foreman }\end{array}$ & $\begin{array}{l}\text { provides new spe- } \\
\text { cification; } \\
\text { signs variation } \\
\text { document }\end{array}$ & $\begin{array}{l}\text { variation docu- } \\
\text { ment, authorized } \\
\text { by signature }\end{array}$ \\
\hline 14 & $\begin{array}{l}\text { SME1 foreman } \\
\rightarrow \text { SME1 op- } \\
\text { erator }\end{array}$ & $\begin{array}{l}\text { translates specifi- } \\
\text { cation; returns to } \\
\text { work on site }\end{array}$ & $\begin{array}{l}\text { solution is being } \\
\text { implemented }\end{array}$ \\
\hline
\end{tabular}

\subsection{Current use of technology}

The following (non-exhaustive) list of material and communication technology which is currently in use on construction sites and in the back-office was put together from interviews with several construction companies:

- drawings on paper

- specifications on paper

- 2D CAD drawings
- photographs

- inspection sheets and non-conformance reports for site supervisor

- time sheets for all resources (human and nonhuman) and processes

- cost management, e.g., spreadsheets

- project management tools in back-office

- progress information forms

- RFI form (request for information) for site engineer to capture information of problem

- diary information for site engineers

- briefing acknowledgements by foreman

- check-lists, e.g., for health \& safety

- written or spoken reports including photographs and sketches

- oral training records for operatives

- photographs of site problems sent to consultant, record of oral conversation with consultant

- notifications of revisions of drawings and specifications on paper

- communication media: (mobile) phone, face-toface meetings, e.g., on site, email, paper, fax.

\section{FUTURE SCENARIO}

\subsection{Future Process}

The future scenario proposed here is based on the current scenario described above. It illustrates the effective use of technology in replacing the need for some of the remote meetings. Its objective is to make the meetings more effective with better common understanding between the participants, to consider more views and for decisions to be reached much faster. As indicated earlier in the current scenario, one of the challenges in the construction industry is to improve communication which currently necessitates several joint meetings, many of them on site. While it might not be possible to force a common language onto the inhomogeneous team, the increased use of visual information, such as pictures, photographs, drawings, video etc. might prove useful in helping the project team share the same views and in providing them with a common and better understanding of the problem. In order to achieve this, information needs to be available and shared much faster between members of the project team independent of their location in an easy way to be understood by those who need it. As a consequence, fewer meetings are required due to communication problems and decisions can be made faster. This will accelerate building in the construction industry and make the collaborators more available for fast responses when their expertise is required for minor issues.

In order to render decision-making more effective and efficient, there is a need for a decision support system which will provide the stakeholders with suggestions of alternative solutions: a knowledge re- 
pository holding the history of problems identified in the past and how they had been solved. This helps the stakeholders not to "re-invent the wheel", but rather to rely on previous solutions, if possible. The problems are classified according to a predefined set of keywords that are relevant to categorize such information. Stakeholders browse the knowledge repository for relevant solutions, based e.g. on similarity patterns.

When the SME1 operator visually identifies the problem concerning the pipe collision as he arrives on site and realizes that the model he has does not correspond with the current situation, he uses his mobile device to take a picture and directly sends it to his foreman to report the problem. There is also an ICT station installed on site which is managed by the Project Manager for communication of large data and in case the mobile communication infrastructure is insufficient. The new technology here offers an opportunity for the SME1 operator to officially communicate to his foreman (who could be located in another site or in the office) and gives the latter an informative picture about the problem by sending digital imagery electronically to the SME and using video conferencing for communicating the problem.

The SME1 foreman needs to communicate the problem to the Project Manager. Since the PM is usually hard to reach, the foreman uses his mobile device to access the system and find out whether the PM is available and how to contact him. In fact, the PM is at his office and can be reached at his PC. PM realizes that this situation indeed presents a problem and sets up a shared virtual workspace. From previous similar problems he finds out who the stakeholders are and invites them to a virtual workspace.

In the communication between the stakeholders, mobile technology plays a crucial part to communicate and exchange information such as video conferencing and the use of digital images. The use of 3D models will assist both the Project Manager and the SME1 foreman to try to find quick solutions for the problem. Fewer face-to-face meetings are required as each will have access to mobile technology.

The SME1 foreman needs to communicate the problem to the Project Manager; since the PM is usually hard to reach, the foreman uses his mobile device to access the system and find out whether the PM is available and how to contact him. In fact, the PM is at his office and can be reached at his PC. PM realizes that this situation indeed presents a problem and sets up a shared virtual workspace: from previous similar problems he finds out who the stakeholders are and invites them to a virtual workspace.

In the communcation between the stakeholders, mobile technology plays a crucial part to communicate and exchange information such as video conferencing and the use of digital images. The use of 3D models will assist both the Project Manager and the SME1 foreman to try to find quick solutions for the problem. Fewer face-to-face meetings are required as each will have access to mobile technology.

RFID technology is used for tagging physical objects at the construction sites, e.g. rooms, pipes, ventilation systems. Thereby the objects can be uniquely identified and related to their contextual data in the back-office. The RFID tag attached to the pipe which is in conflict with ventilation system holds meta data on the pipe's identification and specification. The SME1 foreman uses an RFID antenna to read the tag and then downloads (either to his mobile device or to the ICT station on-site) all relevant material related to that pipe which is stored in the backoffice database. This includes drawings, specifications, check-lists, (non) conformance reports, action history, etc. Recording of actions back to the backoffice system provides a decisional context which can be useful to trace back all decisions and actions that took place e.g. re-engineering, or litigation.

The Project Manager then briefs the SME2 foreman about the problem using similar technology as discussed in the previous stage. As before, the availability and contact database is used to find the best way to reach the foreman.

At this point, another virtual meeting takes place as both SMEs, the Project Manager and the architect speculate about the source of problem (each one of them are in different locations). Augmented reality technology is utilized to impose a virtual 3D model on the real setting: alternative solutions can thus be made visible to the engineers on-site and various options can be discussed - visual information helps reduce the impacts of different "languages" and increases the common understanding between the different cultures in the construction industry.

As the engineers realize that the problem is supply related, they normally would need a site meeting with all members of the design team. By using CoSpaces collaboration technology, however, a site meeting is no longer required and the various members of the design team, together with the Project Manager and the SMEs, will communicate efficiently as if they were all based in the same location by using tele-immersive technology.

As the virtual team meeting results in confirming that the problem is due to lack of space caused by the supplier, the Project Manager communicates with his Contractor Senior Manager for authorization to initiate the solution process. Minutes taken here are contextualized to allow for later reference to them, as are digital images, acquired on site. Communication takes place via an audio/video conference. The same technology can also be used by the PM to discuss the cost implications with his Commercial Director. All relevant outcomes of the various meetings are stored back to the system and thus are available for tracking and for future decision support. 
The engineers, often based at different locations, use simulation tools and 3D models to accommodate the pipe and relocate it. Revised models and drawings are checked back into the system by each of them. The system keeps track of the change history and takes over version management. Meanwhile at the Quantity Surveyor's premises, cost estimation is done using the tools they are familiar with and cost estimation documents are also checked back into the system and - like all other relevant material, history data and meeting data - become part of the pipe's contextual data which can be easily found and retrieved at any time using the RFID tag.

Another virtual meeting takes place involving the PM, SMEs and all members of the design team and minutes and decision reports are taken and stored in context. Minutes, decisions, actions and check-lists and other meeting data are saved and become part of the problem's context. Virtual meetings help reduce the number of face-to-face on-site meetings which results in considerable savings for the project in terms of time and cost as it normally takes days to organize such a meeting to satisfy all the stakeholders.

Having completed the design change documentation about relocating the pipe, the document is made available electronically to the SMEs for timing, resource and costing procedures.

It is worth mentioning that most of the data is exchanged across organizational boundaries and some of it is security relevant. If necessary, confidential data like cost estimates and authorization documents can be securely transferred and the data itself is secured by using encryption technology and authorized using electronic signatures.

The PM communicates with his Contractor Senior Manager by using electronic contracting to issue the final authorization. The PM will then provide the new specification to the SME1 (management, foreman and operator) using an audio/video conference and 3D models. The use of augmented reality will help in instructing the operative to perform their tasks according to the new specifications. The document is then verified by signing it electronically. The operator returns to site to actually relocate the pipe.

\subsection{Current and future practices: added values}

While the nature of the scenario implies that the process of solving the problem will not essentially change in the future, the means to do so has the potential to considerably change in future. Table 3 enhances the description of the current problem solving process, as depicted in table 2,by applying possiblefuture practices.

Table 3: The process of solving unforeseen problems - future practices

\begin{tabular}{llll}
\hline & Actor(s) & Action(s) & Current Practice \\
\hline 1 & SME1 opera- & identifies problem & visually \\
& tor & & \\
& $\begin{array}{l}\text { SME1 opera- } \\
\text { tor } \rightarrow \text { SME1 } \\
\text { foreman }\end{array}$ & reports problem & $\begin{array}{l}\text { physical, mobile } \\
\text { phone, oral report }\end{array}$ \\
& & &
\end{tabular}
man $\rightarrow$ PM

reports problem; consults drawing, tries to find quick solution$$
\text { solution }
$$

4

$\begin{array}{ll}\text { PM } \rightarrow \text { SME2 } & \text { briefs } \\ \text { foreman } & \\ \text { PM }+ \text { SME1 } & \text { speculate about } \\ \text { foreman }+ & \text { source of problem } \\ \text { SME2 } & \\ \text { foreman } & \end{array}$

$\mathrm{PM} \rightarrow$ SME1/SME2 foremen+ engineers $\mathrm{PM} \rightarrow$ Contractor Senior Manager + Commercial Director site meeting: confirm source of problem

informs for authorization to initiate solution process; consider costs, legal, procedural implications instruction to ac- physical, mobile phone, paper drawing

Future Practice

Visually observed, with digital photo and audio/video assistance.

mobile device with camera, video conferencing, RFID technology for identification and contextualization of problem issue.

ICT station on-site for full communication facilities mobile devices with digital imagery and audio/video conferencing, 3D models on stationary PC, VRML models on mobile devices, location tracking of persons, tracking of resources (RFID) to identify relevant drawings on database, check availability and contact data of PM, database of recent similar cases, set up virtual shared workspace with stakeholders

phone, mobile phone, email phone, email, physical meeting, paper drawings, pictures, physical inspection email, meeting, phone, post, fax, drawings, picture, visual inspection physical meeting, phone, email, inhouse system, drawing, pictures mobile devices with digital imagery and audio/video conferencing various options using AR technology on-site are discussed, various $3 \mathrm{D}$ models to investigate options, database of recent similar cases

various options using AR technology on-site are discussed, various $3 \mathrm{D}$ models to investigate options

audio/video conferencing, digital imagery, meeting material (minutes, check-lists, decisions ...), context provision

drawing, 3D mod- $3 \mathrm{D}$ model, potentially simulation and structural analysis 


\begin{tabular}{|c|c|c|c|c|}
\hline & Actor(s) & Action(s) & Current Practice & Future Practice \\
\hline 9 & $\begin{array}{l}\text { PM } \rightarrow \text { Quan- } \\
\text { tity Surveyor }\end{array}$ & $\begin{array}{l}\text { asks for cost esti- } \\
\text { mates }\end{array}$ & $\begin{array}{l}\text { cost estimation us- } \\
\text { ing in-house sys- } \\
\text { tem }\end{array}$ & cost estimates are linked to problem context \\
\hline 10 & $\begin{array}{l}\text { PM } \rightarrow \text { M\&E } \\
\text { engineer + } \\
\text { architect: site } \\
\text { meeting (con- } \\
\text { sultants: } \\
\text { structural, } \\
\text { electrical) + } \\
\text { SME1 fore- } \\
\text { man + SME2 } \\
\text { foreman + } \\
\text { regulatory au- } \\
\text { thorities (fire, } \\
\text { building con- } \\
\text { trol, environ- } \\
\text { ment, police, } \\
\text { planning) }\end{array}$ & $\begin{array}{l}\text { site meeting with } \\
\text { consultants (struc- } \\
\text { tural, electrical): } \\
\text { discuss architectural } \\
\text { design solution and } \\
\text { consider practicabil- } \\
\text { ity issues }\end{array}$ & $\begin{array}{l}\text { physical meeting, } \\
\text { phone, email, } \\
\text { drawings, pictures }\end{array}$ & $\begin{array}{l}\text { mobile collaboration, augmented reality to try out various } \\
\text { options on-site, electronic drawings and pictures }\end{array}$ \\
\hline 11 & SMEs & $\begin{array}{l}\text { verify cost implica- } \\
\text { tions }\end{array}$ & $\begin{array}{l}\text { manual verifica- } \\
\text { tion }\end{array}$ & electronic access to relevant contextual data \\
\hline 12 & $\begin{array}{l}\mathrm{PM} \rightarrow \text { Con- } \\
\text { tractor Senior } \\
\text { Manager }\end{array}$ & $\begin{array}{l}\text { asks for final autho- } \\
\text { rization }\end{array}$ & $\begin{array}{l}\text { post, email, fax, } \\
\text { drawings, contrac- } \\
\text { tual information } \\
\text { on paper }\end{array}$ & $\begin{array}{l}\text { electronic access to relevant contextual data, authorization } \\
\text { document is securely transferred and electronically signed }\end{array}$ \\
\hline 13 & $\begin{array}{l}\mathrm{PM} \rightarrow \mathrm{SME} 1 \\
\text { foreman }\end{array}$ & $\begin{array}{l}\text { provides new speci- } \\
\text { fication; } \\
\text { signs variation doc- } \\
\text { ument }\end{array}$ & $\begin{array}{l}\text { phone, physical } \\
\text { meeting, fax, post, } \\
\text { drawings, contract } \\
\text { on paper, textual } \\
\text { instructions }\end{array}$ & $\begin{array}{l}\text { audio/video conferencing, augmented reality for visualiza- } \\
\text { tion, 3D model, RFID technology for identification of re- } \\
\text { sources }\end{array}$ \\
\hline
\end{tabular}

\section{COSPACES SOFTWARE FRAMEWORK AND MOBILE MAINTENANCE WORKSPACE}

The overall objective of the CoSpaces project is to develop organizational models and distributed technologies that support innovative collaborative workspaces for individuals and project teams within distributed virtual manufacturing enterprises. We explore how advanced technologies such as virtual reality, augmented reality, tele-immersive interfaces, mobile technologies, context-awareness and web services can be deployed in creating human-centric collaborative workspaces for supporting product design and down stream maintenance and constructability processes. The CoSpaces project aims to create an underlying configurable and dynamic software framework so that the system can easily be adapted to suit the user and his/her context (Fernando \& Hansen 2007).

The distributed software framework is validated by three kinds of collaborative working styles required for collaborative design and engineering in three sectors: aerospace, automotive and construction. Three generic classes of collaboration workspaces - distributed design workspace, co-located workspace and mobile workspace - are used to validate the distributed software framework. It is the latter workspace, the Mobile Maintenance Workspace, which is particularly targeted towards the construction industry.

CoSpaces workspaces make use of the services of the CoSpaces software framework. Its main components are depicted in Figure 4. 


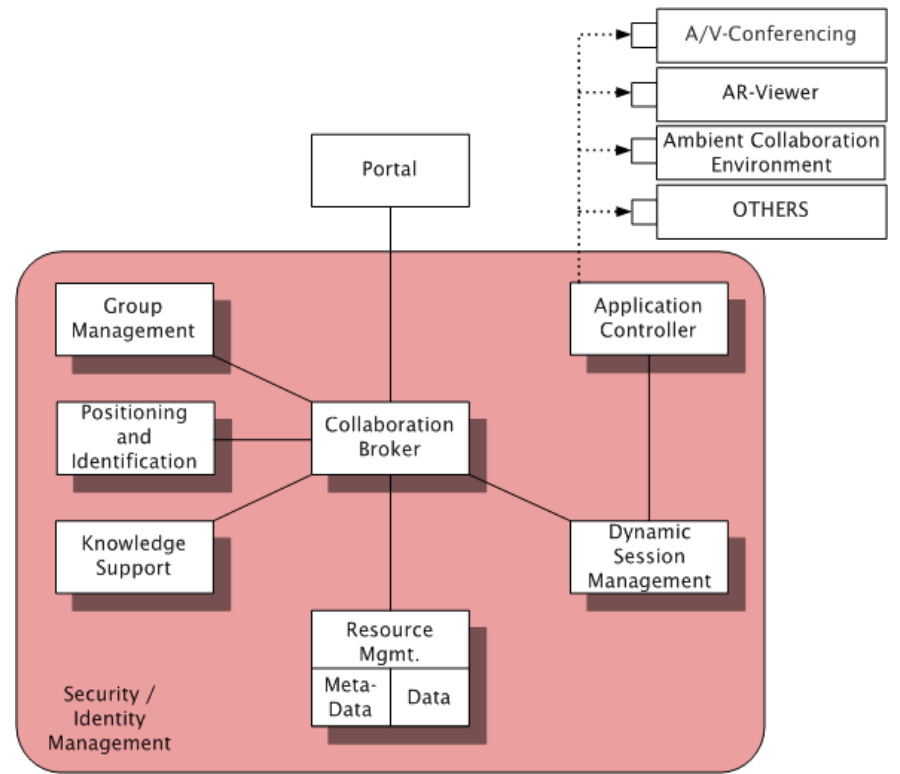

Figure 4: Functional view of the main building blocks of the software framework

Apart from basic services such as Security and Identity Management the Mobile Service Workspace mainly makes use of the following framework components from basic services:

- Portal, the main HTML based user interface entry

- Collaboration Broker, brokering the CoSpaces framework components and serving the Portal

- Group Management service

- Knowledge Support service

- Mobile Augmented Reality framework

\subsection{Mobile access to CoSpaces' services}

For access to general CoSpaces' services at the user interface, we use the Web-based Portal user interface in order to present the end-users with a consistent user interface throughout the various CoSpaces workspace types. While using the Portal as global entry point for accessing CoSpaces services is realistic for laptop devices and state-of-the-art ultra mobile PCs, this is not always the case for other mobile devices such as PDAs. For these devices, specifically designed light-weight mobile applications are provided.

\subsection{Light-weight mobile applications}

For reasons of limited data transfer bandwidth, limited screen size, or limited browser capabilities, both functionality and user interface on mobile devices have to be restricted and adapted to the devices' capabilities. The Mobile Service Workspace concentrates on supporting asynchronous access to the CoSpaces services. Depending on the mobile device capabilities, light-weight mobile applications are provided in addition to the standard Portal access point. The following special mobile applications with a restricted set of functionalities? are currently being implemented (apart from the AR Viewer application mentioned in section 4.3):

- Positioning \& Identification Viewer Identify a person or resource using tracking technology like RFID or WiFi and provide contextualized information about him/her or it.

- Knowledge Viewer

Provide access to a basic set of information stored in the Knowledge Support component and present it in a suitable form on mobile devices.

- People Finder

Browse the personal address book and look for people and their profiles, e.g. when looking for an expert to consult on a problem.

- Presence \& Availability Viewer

Find out who is online and available for being contacted.
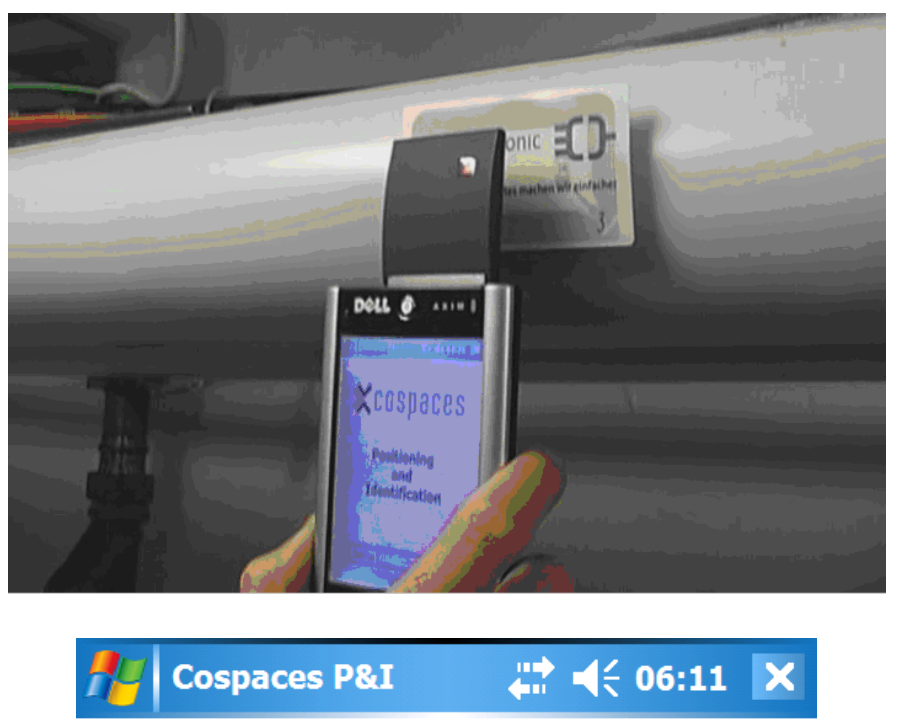

\section{hot water pipe 3}

description: water pipe no. 3 in basement

rfid:

VE00401000081FCOD

location: utility room basement

next_inspection: January 2010

installation_dat $2007-10-04$

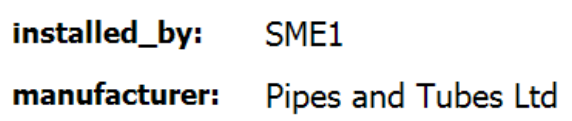

\section{Context}

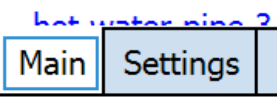

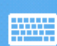

Figure 5: Positioning \& Identification Viewer - user interface 


\subsection{Augmented Reality on mobile devices}

For Augmented Reality applications on mobile devices, we provide a mobile AR software framework. Based on the AR framework Morgan (Ohlenburg et al. 2004), it is particularly suited for the limited capabilities of mobile devices and to their platforms.
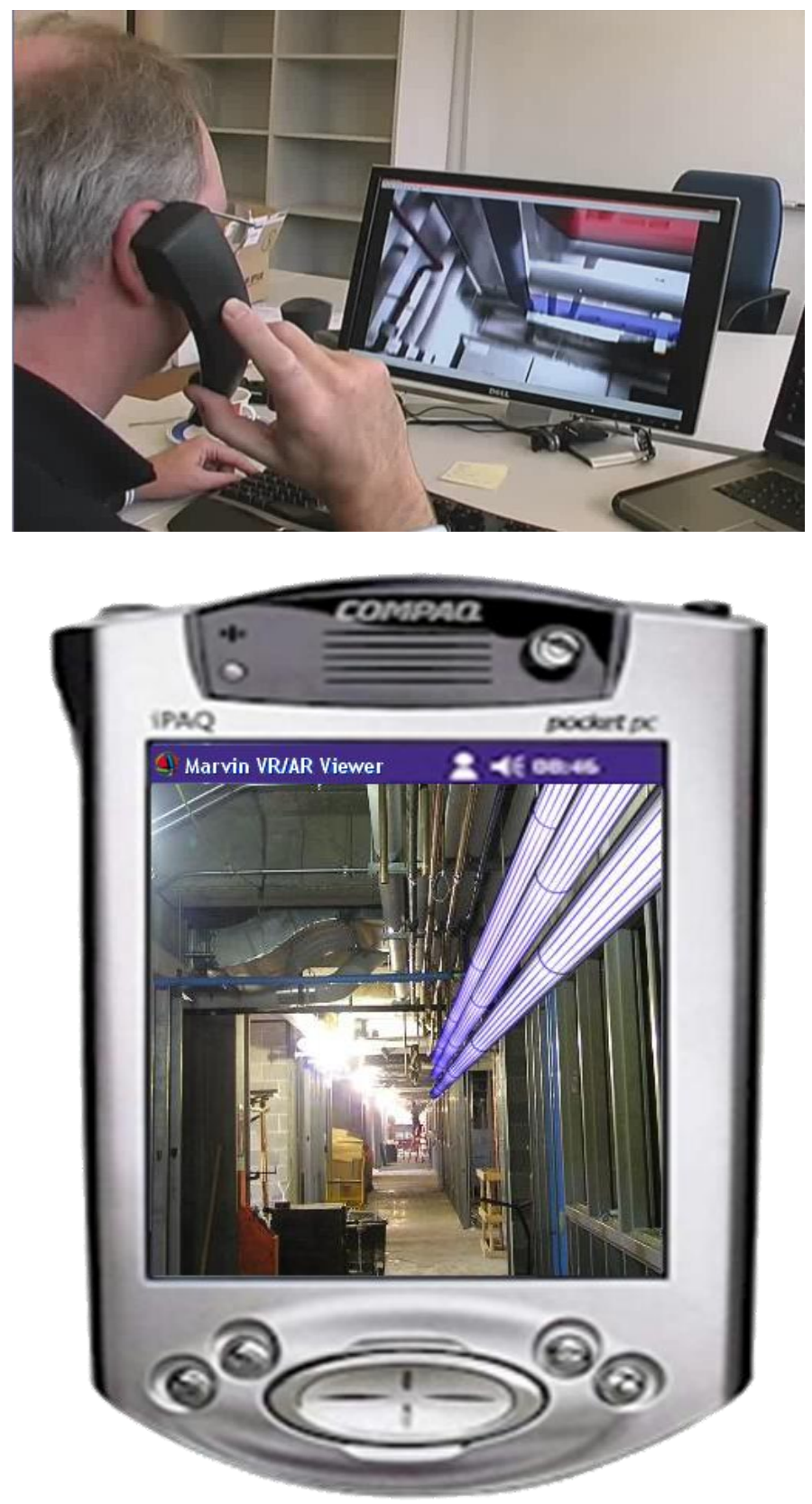

Figure 6: Augmented Reality viewer - desktop and mobile user interfaces

A short demonstration video describing the future scenario of solving unforeseen problems by means of tracking technology and Augmented Reality technology is available for download (Fraunhofer FIT, 2008).

\section{OUTLOOK}

The Mobile Maintenance Workspace is currently being tested and evaluated in Active Distributed Development Spaces by the CoSpaces consortium and in a later phase in a Living Lab at construction sites in the Netherlands and in Denmark. Results from the evaluation are iteratively being fed back into the development process. The CoSpaces project will end in 2009.

\section{ACKNOWLEDGEMENTS}

The scenario described in this paper is the result of many interviews and discussions within the CoSpaces consortium and with external partners. In particular, we would like to express our gratitude to Baz Khan of Amara Heating, Bolton, UK, for his valuable contribution.

\section{REFERENCES}

CoSpaces - EU Integrated Project, IST-5-034245, http://www.cospaces.org/

Fernando, Terrence \& Hansen, Scott, 2007. CoSpaces White Paper. Internal project document.

Fraunhofer FIT, 2008. Mobile Maintenance Prototype. Video, http://www.fit.fraunhofer.de/projects/mixedreality/cospaces/cospaces-mobile-workspacedemonstrator.wmv

Ohlenburg, Jan \& Herbst, Iris \& Lindt, Irma \& Fröhlich, Torsten \& Broll, Wolfgang, 2004. The MORGAN framework: enabling dynamic multi-user AR and VR projects. In proceedings of the Virtual Reality Software and Technology Conference, Hong Kong, China, 2004: 166-169 